\title{
Palladium complexes containing imino phenoxide ligands: synthesis, luminescence, and their use as catalysts for the ring-opening polymerization of rac-lactide
}

\author{
Mrinmay Mandal ${ }^{1,2} \cdot$ Manuela List $^{3} \cdot$ Ian Teasdale $^{4} \cdot$ Günther Redhammer $^{5}$. \\ Debashis Chakraborty $^{6} \cdot$ Uwe Monkowius $^{7}$ (i)
}

Received: 16 November 2017 / Accepted: 26 November 2017/Published online: 12 December 2017

(c) The Author(s) 2017. This article is an open access publication

\begin{abstract}
The preparation, structural characterization, luminescence, and catalytic activity of three palladium(II) complexes bearing imino phenoxide ligands are reported. The X-ray studies revealed that the complexes are mononuclear with palladium centres coordinated in a square-planar coordination environment. Two of the complexes are emissive in solution at room temperature. The catalytic activities towards the ring-opening polymerization of $r a c$-lactide ( $r a c$-LA) were tested. Polymers with moderate molecular weights and relatively broad dispersity $(\nexists)$ were obtained. Kinetic studies revealed that the polymerization followed first-order kinetics.
\end{abstract}

Electronic supplementary material The online version of this article (https://doi.org/10.1007/s00706-017-2119-1) contains supplementary material, which is available to authorized users.

Uwe Monkowius

uwe.monkowius@jku.at

1 Institute of Inorganic Chemistry, Johannes Kepler University Linz, Altenbergerstr. 69, 4040 Linz, Austria

2 School of Chemical and Biomolecular Engineering, Georgia Institute of Technology, Atlanta, GA 30332-0100, USA

3 Institute for Chemical Technology of Organic Materials, Johannes Kepler University Linz, Altenbergerstr. 69, 4040 Linz, Austria

4 Institute of Polymer Chemistry, Johannes Kepler University Linz, Altenbergerstr. 69, 4040 Linz, Austria

5 Materialwissenschaften und Physik, Abteilung für Mineralogie, Paris-Lodron Universität Salzburg, Hellabrunner Str. 34, 5020 Salzburg, Austria

6 Department of Chemistry, Indian Institute of Technology Madras, Chennai, Tamil Nadu 600 036, India

7 Linz School of Education, Johannes Kepler University Linz, Altenbergerstr. 69, 4040 Linz, Austria
Graphical abstract

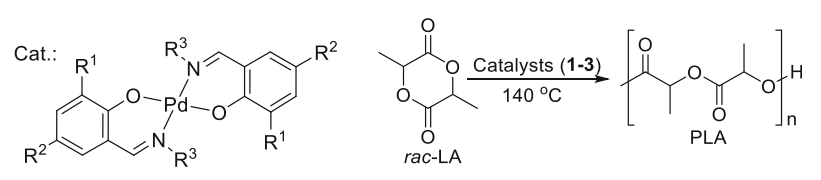

Keywords Imino phenoxide $\cdot$ Palladium $\cdot$ Crystal structure $\cdot$ ROP $\cdot r a c$-Lactide $\cdot$ Luminescence

\section{Introduction}

Tetradentate salen-type ligands are omnipresent in coordination chemistry. They are easy to synthesize and they exhibit a high structural variability due to a large number of commercial available building blocks which can be used as starting materials. In many cases, they form highly stable metal complexes throughout the whole periodic table and a plethora of metal complexes have been reported in the past $[1,2]$. Related imino phenoxide ligands could be considered as half salen-type ligands and are somewhat less frequently used as ligands. They also exhibit similar advantageous coordination modes, i.e. the combination of a moderate hard and a hard donor atom with an anionic nature of the ligand. Hence, reports from almost all areas of coordination chemistry have been published up to now. Such complexes have found applications in catalysis or biochemistry or feature interesting structural, magnetic, photophysical or electrochemical properties [3-12].

Besides ubiquitous applications in catalysis for coupling reactions, palladium complexes were intensively investigated due to their interesting luminescence properties $[13,14]$. However, only limited number of papers has been 
published investigating emissive properties using salentype or imino phenoxide ligands [15]. Palladium in its oxidation state +2 has a $\mathrm{d}^{8}$ configuration and hence prefers a square-planar coordination. It is well known that such complexes form polymeric columnar structures, often with infinite and close Pd-Pd bonds. Contrary to their platinum congeners [16], such complexes usually do not feature luminescence from excited states based on these metallophilic interactions. However, Pd(II) complexes bearing ligands with energetic low-lying $\pi^{*}$-accepting orbitals exhibit phosphorescence from either metal-to-ligand charge transfer $\left({ }^{3} \mathrm{MLCT}\right)$ or intraligand $\left({ }^{3} \mathrm{IL}\right)$ excited states [17].

In recent publications we have shown that main group as well as transition metal imino phenoxide complexes can be used as polymerization catalysts, e.g. for the preparation of polyesters like poly(lactic acid) (PLA) and poly(caprolactone) (PCL) [18-23]. They constitute an interesting family of environmentally benign biodegradable polymers with a wide variety of potential applications in the biomedical area or as alternatives to persistent polyolefin materials [24-29]. Usually, aliphatic polyesters are prepared by the ring-opening polymerization (ROP) of cyclic esters using metal-based initiators, particularly of toxic tin containing compounds. In the past years, much effort has been spent in studies with alternative catalyst systems containing other, partly less toxic metals [30-37].

In this contribution, we report on the synthesis, structural characterization, photophysical, and catalysis studies of some square-planar Pd(II) complexes bearing imino phenoxide ligands with different structural modifications. Furthermore, although similar Pd(II) complexes have been prepared previously, to the best of our knowledge, the catalysis for the ROP of rac-LA using Pd(II) complexes containing the imino phenoxide backbone is still unreported [38-43].

\section{Results and discussion}

\section{Synthesis and characterization}

The ligands were prepared following a reported literature procedure $[44,45]$. The complexes were synthesized by mixing an ethanolic solution of the Schiff base and Pd(II) acetate in refluxing ethanol (Scheme 1).

Complexes 1-3 were isolated in high yields. Their identity and purity are supported by elemental analysis, NMR spectroscopy, and mass spectrometry. In the ESI-MS spectra, signals representing the ions $\left[\mathrm{L}_{2} \mathrm{PdH}\right]^{+}$and $\left[\mathrm{L}_{2-}\right.$ $\mathrm{PdNa}]^{+}$are detected. The IR spectra of the free ligands show intense signals in the region from 1623 to $1632 \mathrm{~cm}^{-1}$
(Fig. S10). In the complexes, the spectra are shifted towards lower frequencies $\left(1607-1624 \mathrm{~cm}^{-1}\right)$, which eventually revealed the coordination of imine nitrogen atoms to the metal (Fig. S11). In the ${ }^{1} \mathrm{H}$ NMR spectra, the formation of the metal complexes is shown by the disappearance of the phenol $-\mathrm{OH}$ signals of the ligands. In addition, the signals corresponding to the protons of the $\mathrm{CH}=\mathrm{N}$ groups appear low field shifted $(7.52-7.59 \mathrm{ppm})$ compared to those of the ligands $(8.4-8.6 \mathrm{ppm})$ which indicates the coordination of nitrogen and oxygen atoms of the ligands to the metal.

\section{Structural studies}

Single crystals suitable for X-ray diffraction of all three complexes were grown by slow evaporation of the solvent from their solutions in dichloromethane over a period of 1 week. All complexes were obtained as red crystalline solids. The crystallographic data are summarized in Table 4. Molecular structures and selected bond lengths and bond angles are displayed in Fig. 1 and Table 1, respectively. Complex 1 crystallizes in the monoclinic space group $P 2_{1} / n$, complex 2 in the triclinic space group $P$ $\overline{1}$, both with one half formula units in the asymmetric unit with the palladium atom as the inversion centre. Complex $\mathbf{2}$ is isostructural to the homologues copper(II) complex [12]. The palladium atom is coordinated by two nitrogen and two oxygen atoms with an angular sum of exact $180^{\circ}$ indicative for a perfect planar coordination. The coordination geometry of $\mathbf{2}$ is further stabilized by $\mathrm{C}-\mathrm{Br} / \pi$ interactions: the bromine atom points directly to $\pi$-system of the phenyl-group of the aniline moiety with a distance between the ring plane and the bromine atom of $\sim 3.44 \AA$ which is typical for this kind of interactions [46, 47]. Similarly, for $\mathbf{1}$ the methyl-substituents are engaged in C$\mathrm{H} / \pi$-interactions. 3 is monoclinic, $P \overline{1}$ with two complexes per asymmetric unit. Contrary to $\mathbf{1}$ and $\mathbf{2}$, the palladium atom in $\mathbf{3}$ exists in a strongly distorted square-planar coordination environment [angular sum $362.0^{\circ}$ (Pd1)/ $\left.361.1^{\circ}(\mathrm{Pd} 2)\right]$. This might be due to steric reasons and packing effects. The palladium atoms in all complexes are not engaged in any further Pd-Pd interactions.

\section{Electronic spectra}

The electronic spectra of all the complexes were recorded in solution at room temperature (Fig. 2). The data are summarized in Table 2 . The absorption spectra are very similar to the reported ones [39, 40, 42]. The presence of bands below $300 \mathrm{~nm}$ is assigned to $\pi-\pi^{*}$ transition of the ligands. The long wavelength absorptions can be assigned to an MLCT. Related Pd(II) complexes bearing salen-type ligands are sometimes only weakly emissive. An recent 
Scheme 1

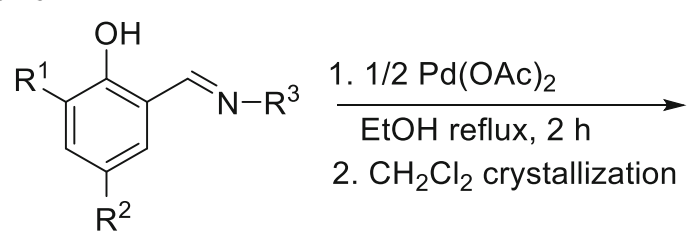<smiles></smiles>

L1 $\mathrm{R}^{1}=\mathrm{R}^{2}=\mathrm{Me} ; \mathrm{R}^{3}=(4-\mathrm{MeO}) \mathrm{C}_{6} \mathrm{H}_{4}$

L2 $\mathrm{R}^{1}=\mathrm{R}^{2}=\mathrm{Br} ; \mathrm{R}^{3}=\left(2,6-i-\mathrm{Pr}_{2}\right) \mathrm{C}_{6} \mathrm{H}_{3}$

L3 $\mathrm{R}^{1}=t-\mathrm{Bu}, \mathrm{R}^{2}=\mathrm{Me} ; \mathrm{R}^{3}=(4-\mathrm{MeO}) \mathrm{C}_{6} \mathrm{H}_{4} \mathrm{CH}_{2}$

Ligand Compound Yield $/ \%$

\begin{tabular}{lll}
\hline L1 & $\mathbf{1}$ & 79 \\
L2 & $\mathbf{2}$ & 73 \\
L3 & $\mathbf{3}$ & 75
\end{tabular}
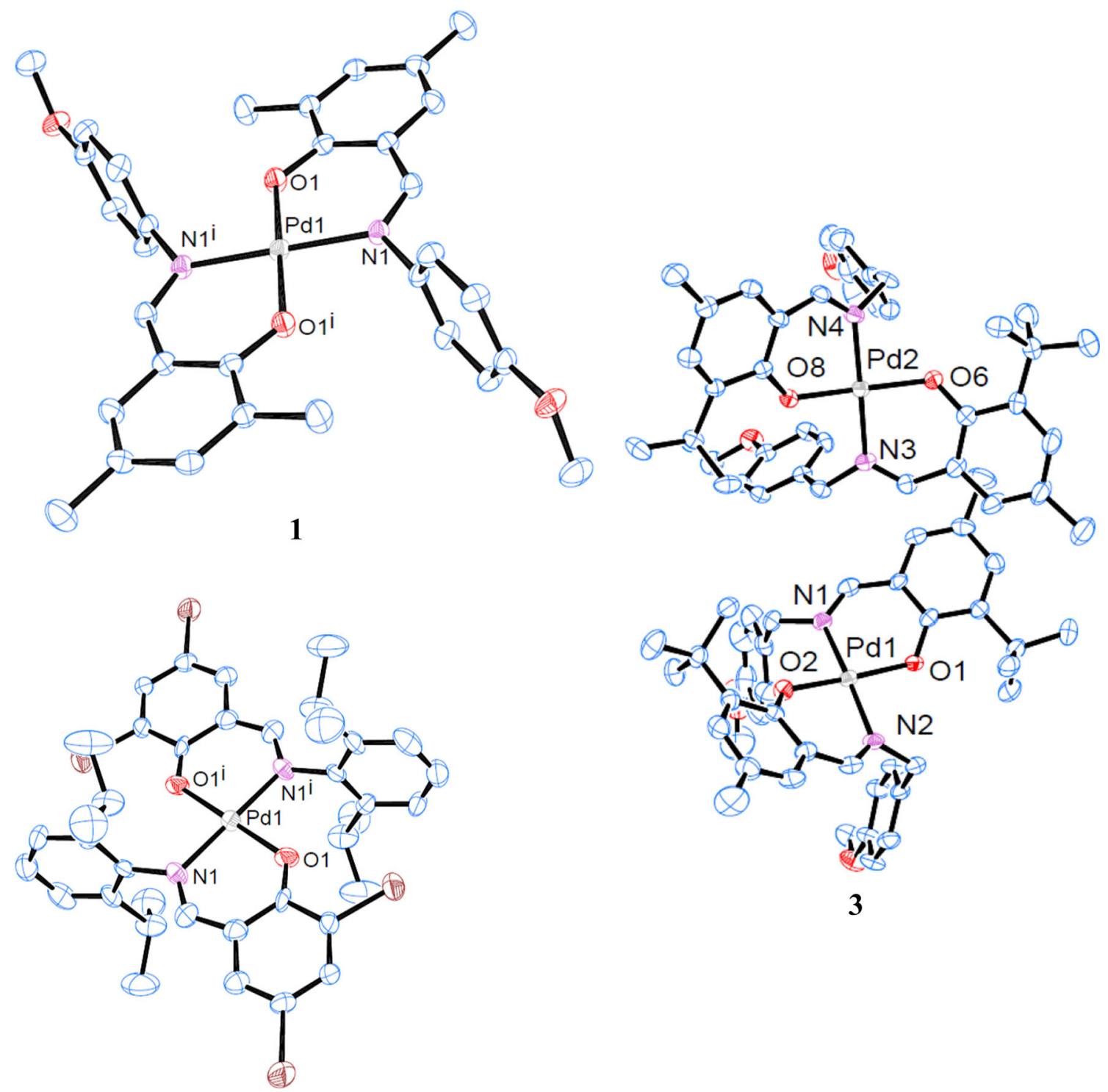

3

2

Fig. 1 Molecular structures of 1-3; thermal ellipsoids were drawn at 50\% probability level. Hydrogen atoms were removed for clarity 
Table 1 Selected bond lengths $/ \AA$ and bond angles $/{ }^{\circ}$ for $\mathbf{1 - 3}$

\begin{tabular}{llll}
\hline & $\mathbf{1}$ & $\mathbf{2}$ & $\mathbf{3}$ \\
\hline Pd-N & $2.021(2)$ & $2.020(12)$ & $2.028(6)$ \\
& & & $2.035(7)$ \\
& & $1.996(5)$ \\
& & $2.021(5)$ \\
Pd-O & $1.975(2)$ & $1.986(11)$ & $1.982(5)$ \\
& & & $1.982(5)$ \\
& & & $1.996(5)$ \\
& & & $2.005(5)$ \\
O-Pd-N & & & $90.6(2) / 90.4(2)(\mathrm{Pd} 1)$ \\
& & & $90.4(2) / 89.6(2)(\mathrm{Pd} 2)$ \\
O-Pd-N & & & $90.1(2) / 90.4(2)(\mathrm{Pd} 1)$ \\
& & & $90.9(2) / 89.7(2)(\mathrm{Pd} 2)$ \\
\hline
\end{tabular}

${ }^{\mathrm{a}}$ Bite angle

theoretical study on Pd(II) salen complexes explains the poor emissive behaviour by a low energy gap between emissive MLCT and quenching dd excited states [15]. The authors suggest a substitution of the ligands with strongly electron-withdrawing ligands. Indeed, the ligand in complex 2 carries the moderately electron-withdrawing bromine substituent, whereas the ligand in the non-emissive complex $\mathbf{1}$ is substituted by a strongly electrondonating methoxy group. For $\mathbf{3}$, the ligand is substituted with a very bulky $t$-butyl group which leads not only to a strongly distorted coordination geometry as elucidated by the solid state structure, but also to a more rigid structure with respect to a distortion in the excited state. Minimizing the excited state structural distortion has been found to be effective in increasing the luminescence quantum yield. It should be noted that analogous Pt-complexes often feature intensive luminescence [14].

\section{Polymerization studies}

The complexes 1-3 were investigated as catalysts for ROP of rac-LA (Scheme 2). The kinetics of polymerization was examined by ${ }^{1} \mathrm{H}$ NMR spectroscopy. The polymerization was performed in a 200:1 ratio ([rac$\left.\mathrm{LA}]_{0} /[\mathrm{Cat}]_{0}=200: 1\right)$ catalysed by complexes 1-3. The plot of $\%$ conversion of rac-LA against time gives a sigmoid curve meaning that initially the conversion rate is high but decreases significantly at later stage (Fig. 3, left). There is a linear correlation of the values in the semi-logarithmic plot of $\ln \left([\mathrm{rac}-\mathrm{LA}]_{0} /[\mathrm{rac}-\mathrm{LA}]_{\mathrm{t}}\right)$ vs. time indicative for a first-order dependency on the monomer concentrations with the absence of any induction period (Fig. 3, right). This result suggests that the active species

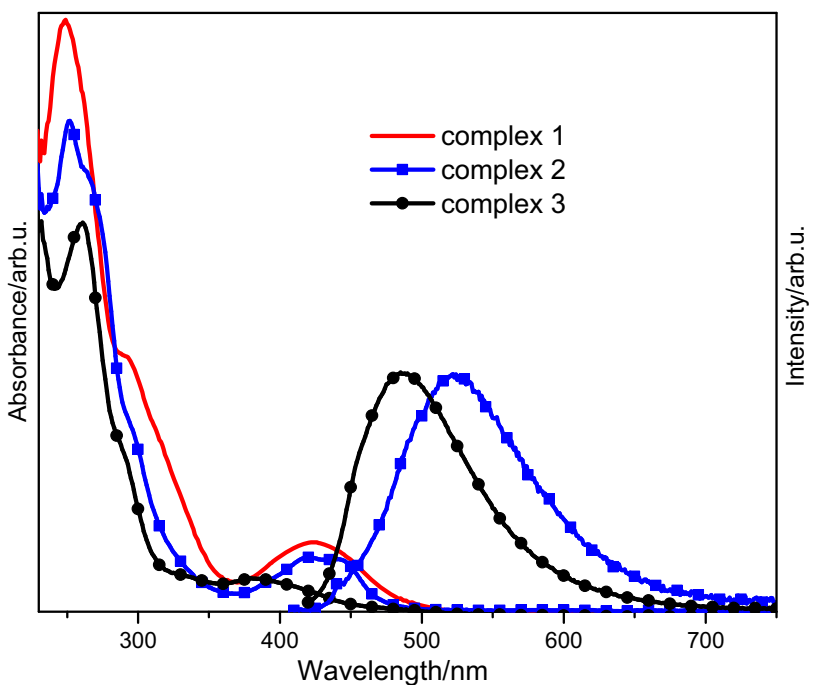

Fig. 2 UV-Vis absorption and emission spectra of 1-3 in DCM at room temperature

remained unchanged and active during the entire course of polymerization. The apparent rate constants $\left(k_{\mathrm{app}}\right)$ were extracted from the linear plot of $\ln \left([\mathrm{rac}-\mathrm{LA}]_{0} /[\mathrm{rac}-\right.$ $\mathrm{LA}]_{\mathrm{t}}$ ) vs. time and were found to be $3.47 \times 10^{-2} \mathrm{~min}^{-1}$, $2.14 \times 10^{-2} \mathrm{~min}^{-1}$, and $2.84 \times 10^{-2} \min ^{-1}$ for $\mathbf{1 - 3}$, respectively (Fig. 2, right), i.e. the activities of the catalysts are slightly higher than those found for the copper(II) homologue complexes we reported previously [12].

Furthermore, bulk polymerizations were performed in a 200:1 (monomer:catalyst) ratio at a temperature of $140{ }^{\circ} \mathrm{C}$ and the polymerization was terminated once the rise in the viscosity was observed and the stirring finally ceased. In these experiments, all complexes exhibits a comparable activity to that already found for the kinetic studies above. The representative results are displayed in Table 3. All complexes yielded polymers with moderate molecular weight $\left(M_{\mathrm{n}}\right)$ and relatively broad dispersities $\left(M_{\mathrm{w}} /\right.$ $\left.M_{\mathrm{n}}=1.91-1.98\right)$. The large difference between the experimental and theoretic values and broad $D$ compared to literature values [48] are thought to be due to the occurrence of polymerization side reactions such as intermolecular or intra-molecular transesterification as well as a slow initiation rate compared with a fast propagation [49-52].

\section{Conclusion}

In conclusion, we have synthesized three new palladium complexes containing imino phenoxide ligands. The single-crystal X-ray analysis revealed that the palladium atom 
Table 2 UV/Vis spectroscopic data of the complexes 1-3

\begin{tabular}{lll}
\hline Compound & Absorption $\lambda / \mathrm{nm}\left[\log \left(\varepsilon / \mathrm{dm}^{3} \mathrm{~mol}^{-1} \mathrm{~cm}^{-1}\right)\right]$ & Emission/nm \\
\hline $\mathbf{1}$ & $247(4.77), 293(4.41), 423(3.84)$ & - \\
$\mathbf{2}$ & $252(4.79), 267(\mathrm{sh}, 4.73), 295(\mathrm{sh}, 4.38), 420(3.83), 431(3.82)$ & 522 \\
$\mathbf{3}$ & $261(4.75), 289(\mathrm{sh}, 4.37), 334(3.72), 385(3.66)$ & 487 \\
\hline
\end{tabular}

Scheme 2<smiles>CC(C)OC(C)C(=O)OC(C)C(=O)C(C)(C)C(C)C</smiles>

is surrounded by two ligands in a square-planar coordination environment. Complex $\mathbf{2}$ and $\mathbf{3}$ are emissive in solution at room temperature. These compounds have catalytic activity towards the polymerization of rac-LA. The $M_{\mathrm{n}}$ of the polymers is moderate with relatively broad $M_{\mathrm{w}} / M_{\mathrm{n}}$ values.

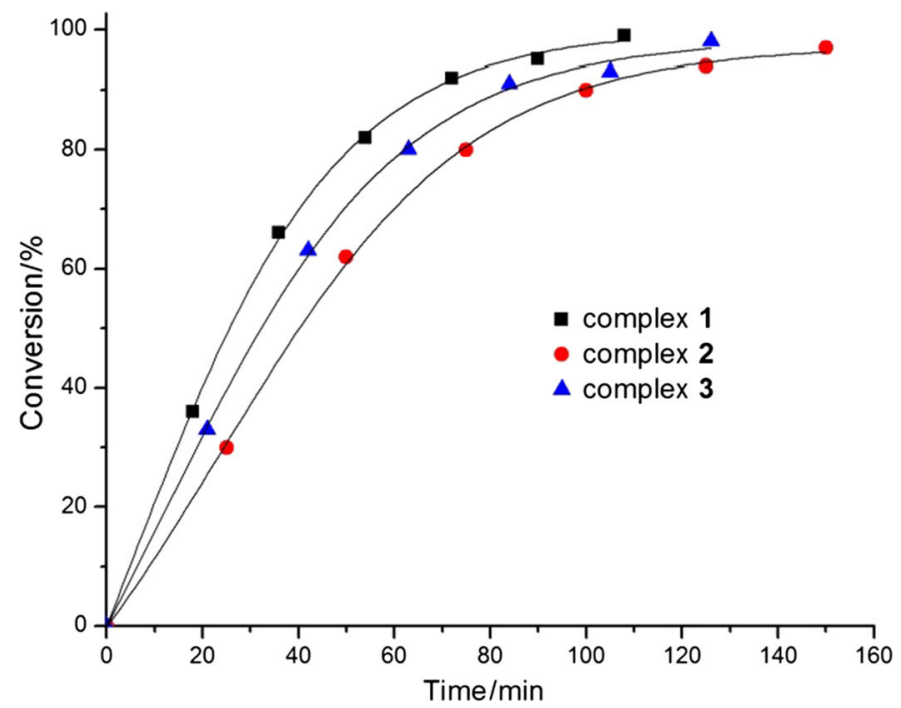

\section{Experimental}

All manipulations were carried out in an atmosphere of dry nitrogen using standard Schlenk techniques. $\mathrm{CDCl}_{3}$ used for NMR spectral measurements was dried over calcium hydride for $48 \mathrm{~h}$, distilled and stored in a glove box. ${ }^{1} \mathrm{H}$ and ${ }^{13} \mathrm{C}\left\{{ }^{1} \mathrm{H}\right\}$ NMR spectra were recorded in Bruker Digital Avance III (300 MHz) instrument. Chemical shifts for ${ }^{1} \mathrm{H}$ was referenced to residual solvent resonances and are reported as parts per million relative to $\mathrm{SiMe}_{4}$. IR spectroscopy was performed on a Shimadzu IRAffinity-1 FTIR spectrophotometer that was equipped with a Specac Golden GateTM single-reflection diamond ATR accessory. Mass spectra were collected on a Finnigan LCQ DecaXPPlus ion trap mass spectrometer with

Fig. $3 \mathrm{rac}-\mathrm{LA}$ conversion vs. time (left) and $\ln \left([\mathrm{rac}-\mathrm{LA}]_{0} /[\mathrm{rac}-\mathrm{LA}]_{\mathrm{t}}\right)$ vs. time plot (right) using 1-3: $[\mathrm{rac}-\mathrm{LA}]_{0}:[\mathrm{Cat}]_{0}=200: 1$ at $140{ }^{\circ} \mathrm{C}$

Table 3 Polymerization data for $r a c$-LA using 1-3 in 200:1 (monomer:catalyst) ratio at $140{ }^{\circ} \mathrm{C}$

\begin{tabular}{lllllll}
\hline Entry & Catalyst & Yield $/ \%$ & Time $/ \mathrm{min}$ & $M_{\mathrm{n}}^{\mathrm{obs}} / \mathrm{kg} \mathrm{mol}^{-1}$ & $M_{\mathrm{w}} / M_{\mathrm{n}}$ & $k_{\mathrm{app}} / 10^{-2} \mathrm{~min}^{-1}$ \\
\hline 1 & $\mathbf{1}$ & 99 & 109 & 12.89 & 1.91 & 3.47 \\
2 & $\mathbf{2}$ & 97 & 153 & 10.02 & 1.98 & 2.14 \\
3 & $\mathbf{3}$ & 98 & 128 & 10.54 & 1.94 & 2.84 \\
\hline
\end{tabular}

${ }^{\mathrm{a}}$ Time of polymerization measured by quenching the polymerization reaction when stirring ceased 
Table 4 Crystal structure data for 1-3

\begin{tabular}{|c|c|c|c|}
\hline Complex & 1 & 2 & 3 \\
\hline Empirical formula & $\mathrm{C}_{32} \mathrm{H}_{32} \mathrm{~N}_{2} \mathrm{O}_{4} \mathrm{Pd}$ & $\mathrm{C}_{38} \mathrm{H}_{40} \mathrm{Br}_{4} \mathrm{~N}_{2} \mathrm{O}_{2} \mathrm{Pd}$ & $\mathrm{C}_{40} \mathrm{H}_{48} \mathrm{~N}_{2} \mathrm{O}_{4} \mathrm{Pd}$ \\
\hline Formula weight & 615.00 & 982.76 & 727.20 \\
\hline Crystal system & Monoclinic & Triclinic & Triclinic \\
\hline Space group & $P 2_{1} / n$ & $P \overline{1}$ & $P \overline{1}$ \\
\hline$a / \AA$ & $12.7329(12)$ & $9.35(2)$ & $14.9031(15)$ \\
\hline$b / \AA$ & $9.3575(10)$ & $9.46(2)$ & $15.4962(16)$ \\
\hline$c / \AA$ & $12.7447(12)$ & $12.40(2)$ & $17.2469(16)$ \\
\hline$\alpha /^{\circ}$ & 90 & $112.25(2)$ & $72.462(3)$ \\
\hline$\beta /^{\circ}$ & $12.7447(12)$ & $95.71(2)$ & $77.170(3)$ \\
\hline$\gamma /{ }^{\circ}$ & 90 & $99.12(2)$ & $80.781(3)$ \\
\hline$V / \AA^{3}$ & $1382.7(2)$ & 987 (4) & $3684.4(6)$ \\
\hline$Z$ & 2 & 1 & 4 \\
\hline Temp/K & $260(2)$ & $300(2)$ & $300(2)$ \\
\hline$D_{\text {calc }} / \mathrm{g} \mathrm{cm}^{-3}$ & 1.477 & 1.654 & 1.311 \\
\hline Reflns collected & 24,978 & 3725 & 32,284 \\
\hline Unique reflns & 2444 & 1628 & 12,644 \\
\hline Observ. reflns $[I \geq 2 \sigma(I)]$ & 1949 & 1192 & 7636 \\
\hline Param. refined/restraints & $181 / 0$ & $220 / 0$ & $868 / 0$ \\
\hline Absorption correction & Multi-scan & Multi-scan & Multi-scan \\
\hline$T_{\min } / T_{\max }$ & $0.68 / 0.85$ & $0.61 / 0.74$ & $0.24 / 0.89$ \\
\hline$R_{1} / w R_{2}$ & $0.032 / 0.086$ & $0.056 / 0.160$ & $0.094 / 0.237$ \\
\hline$\Delta \sigma_{\text {fin }}(\max / \min ) / \mathrm{e}^{-3}$ & $0.29 /-0.71$ & $0.17 /-0.15$ & $1.49 /-1.22$ \\
\hline $\mathrm{CCDC}$ & 1585795 & 1585796 & 1585797 \\
\hline
\end{tabular}

$R_{1}=\sum\left|F_{0}\right|-\left|F_{\mathrm{c}}\right| / \sum\left|F_{0}\right|, w R_{2}=\left[\sum\left(F_{0}^{2}-F_{\mathrm{c}}^{2}\right)^{2} / \sum w\left(F_{0}^{2}\right)^{2}\right]^{1 / 2}$ an ESI ion source. Elemental analyses were carried out at the Institute for Chemical Technology of Organic Materials at Johannes Kepler University Linz. MALDITOF measurements were performed on a Bruker Daltonics instrument in a dihydroxybenzoic acid matrix. For photophysical characterization, spectroscopic grade solvents were used throughout all measurements. Absorption spectra were recorded with a Varian Cary 50 Conc spectrophotometer. All $\varepsilon$ values are given in $\mathrm{dm}^{3}$ $\mathrm{mol}^{-1} \mathrm{~cm}^{-1}$.

Dichloromethane was dried and distilled over $\mathrm{K}_{2} \mathrm{CO}_{3}$, and ethanol was dried and distilled over sodium. $\mathrm{Pd}(\mathrm{OAc})_{2}$ (Sigma-Aldrich) was used without further purification. racLA (Sigma-Aldrich) was sublimed under an argon atmosphere repeatedly for further purification and stored in a glove box. All other solvents and reagents were commercially available and used as received. Ligands $\mathbf{L 1}-\mathbf{L} 3$ were prepared according to literature-reported procedures [44, 45]. Polymerization experiments and characterization of the polymers were performed according to described procedures [12].

\section{General procedure for the synthesis of $1-3$}

The ethanolic solution $\left(10 \mathrm{~cm}^{3}\right)$ of the Schiff base $(1 \mathrm{mmol})$ and the palladium acetate $(0.5 \mathrm{mmol})$ in $10 \mathrm{~cm}^{3}$ ethanol were mixed thoroughly and the mixture was heated under reflux for $2 \mathrm{~h}$ and then cooled to room temperature. After filtration the resulting solution was evaporated to dryness and the residue was recrystallized from dichloromethane.

Bis[2-[(4-methoxyphenyl)iminomethyl]-4,6-dimethylphenolato- $\kappa^{2} N, O^{I}$ ]palladium(II) $\left(\mathbf{1}, \mathrm{C}_{32} \mathrm{H}_{32} \mathrm{~N}_{2} \mathrm{O}_{4} \mathrm{Pd}\right)$ Yield: $0.07 \mathrm{~g}$ (79\%); ${ }^{1} \mathrm{H}$ NMR $\left(300 \mathrm{MHz}, \mathrm{CDCl}_{3}\right)$ : $\delta=1.26\left(\mathrm{~s}, \mathrm{CH}_{3}, 6 \mathrm{H}\right), 2.12\left(\mathrm{~s}, \mathrm{CH}_{3}, 6 \mathrm{H}\right), 3.84(\mathrm{~s}, \mathrm{Ar}-\mathrm{O}-$ $\left.\mathrm{CH}_{3}, 6 \mathrm{H}\right), 6.76$ (s, $\left.A r-\mathrm{H}, 2 \mathrm{H}\right), 6.83$ (s, $\left.A r-\mathrm{H}, 2 \mathrm{H}\right), 6.90-$ $6.93(\mathrm{~d}, J=9 \mathrm{~Hz}, A r-\mathrm{H}, 4 \mathrm{H}), 7.33-7.36(\mathrm{~d}, J=9 \mathrm{~Hz}, A r-$ $\mathrm{H}, 4 \mathrm{H}), 7.59$ (s, $C H=\mathrm{N}, 2 \mathrm{H}) \mathrm{ppm} ;{ }^{13} \mathrm{C}\left\{{ }^{1} \mathrm{H}\right\} \mathrm{NMR}(75 \mathrm{MHz}$, $\left.\mathrm{CDCl}_{3}\right): \delta=15.77\left(\mathrm{CH}_{3}\right), 20.10\left(\mathrm{CH}_{3}\right), 55.88(\mathrm{Ar}-\mathrm{O}-$ $\mathrm{CH}_{3}$ ), 114.26 ( $\left.\mathrm{Ar}-\mathrm{C}\right), 114.74(\mathrm{Ar}-\mathrm{C}), 119.05$ ( $\left.\mathrm{Ar}-\mathrm{C}\right)$, 123.60 (Ar-C), 125.48 (Ar-C), 129.59 (Ar-C), 131.23 (Ar-C), 137.09 (Ar-C), 144.06 (Ar-C), 158.37 (Ar-O), 
$163.35(\mathrm{CH}=\mathrm{N})$ ppm; IR (ATR): $\bar{v}=1617(-\mathrm{CH}=\mathrm{N}), 1506$ (Ar-OMe) $\mathrm{cm}^{-1}$; MS (ESI): $\mathrm{m} / z$ calculated for $\mathrm{C}_{32} \mathrm{H}_{32} \mathrm{~N}_{2-}$ $\mathrm{O}_{4} \mathrm{PdNa}\left([\mathrm{M}+\mathrm{Na}]^{+}\right)$637.13, found 637.33.

\section{Bis[2,4-dibromo-6-[(2,6-diisopropylphenyl)imi-} nomethyl]phenolato- $\kappa^{2} N, O^{1}$ Jpalladium(II)

$\left(2, \mathrm{C}_{38} \mathrm{H}_{40} \mathrm{Br}_{4} \mathrm{~N}_{2} \mathrm{O}_{2} \mathrm{Pd}\right)$

Yield: $0.07 \mathrm{~g}(73 \%) ;{ }^{1} \mathrm{H}$ NMR $\left(300 \mathrm{MHz}, \mathrm{CDCl}_{3}\right)$ : $\delta=1.17-1.20\left(\mathrm{~d}, J=9 \mathrm{~Hz}, \mathrm{CH}\left(\mathrm{CH}_{3}\right)_{2}, 12 \mathrm{H}\right), 1.29-1.32$ $\left(\mathrm{d}, \mathrm{J}=9 \mathrm{~Hz}, \mathrm{CH}\left(\mathrm{CH}_{3}\right)_{2}, 12 \mathrm{H}\right), 3.52-3.66\left(\mathrm{~m}, \mathrm{CH}\left(\mathrm{CH}_{3}\right)_{2}\right.$, $4 \mathrm{H}), 7.15-7.16(\mathrm{~d}, J=3 \mathrm{~Hz}, A r-\mathrm{H}, 2 \mathrm{H}), 7.18-7.19$ (d, $J=3 \mathrm{~Hz}, A r-\mathrm{H}, 2 \mathrm{H}), 7.21(\mathrm{~s}, A r-\mathrm{H}, 3 \mathrm{H}), 7.28-7.29$ (d, $J=3 \mathrm{~Hz}, A r-\mathrm{H}, 1 \mathrm{H}), 7.44(\mathrm{~s}, A r-\mathrm{H}, 2 \mathrm{H}), 7.52-7.53$ (d, $J=3 \mathrm{~Hz}, \mathrm{CH}=\mathrm{N}, 2 \mathrm{H}) \mathrm{ppm} ;{ }^{13} \mathrm{C}\left\{{ }^{1} \mathrm{H}\right\}$ NMR $(75 \mathrm{MHz}$, $\left.\mathrm{CDCl}_{3}\right): \delta=23.48\left(\mathrm{CH}\left(\mathrm{CH}_{3}\right)_{2}\right), 24.42\left(\mathrm{CH}\left(\mathrm{CH}_{3}\right)_{2}\right), 28.81$ $\left(\mathrm{CH}\left(\mathrm{CH}_{3}\right)_{2}\right), 105.27$ ( $\left.\mathrm{Ar}-\mathrm{C}\right), 114.32$ (Ar-C), 120.93 (ArC), 124.70 ( $A r-C), 127.54(A r-C), 135.44$ ( $A r-C), 140.31$ (Ar-C), 142.02 (Ar-C), 145.07 (Ar-C), 159.98 (Ar-O), $163.25(\mathrm{CH}=\mathrm{N}) \mathrm{ppm}$; IR (ATR): $\bar{v}=1607(-\mathrm{CH}=\mathrm{N}) \mathrm{cm}^{-1}$; MS (ESI): $\mathrm{m} / \mathrm{z}$ calculated for $\mathrm{C}_{38} \mathrm{H}_{41} \mathrm{Br}_{4} \mathrm{~N}_{2} \mathrm{O}_{2} \mathrm{Pd}$ $\left([\mathrm{M}+\mathrm{H}]^{+}\right)$983.780, found 983.497.

Bis[2-[(4-methoxybenzyl)iminomethyl]-4-methyl-6-(tertbutyl)phenolato- $\kappa^{2} N, O^{1}$ Jpalladium(II)

$\left(3, \mathrm{C}_{40} \mathrm{H}_{48} \mathrm{~N}_{2} \mathrm{O}_{4} \mathrm{Pd}\right)$

Yield: $0.06 \mathrm{~g}(75 \%) ;{ }^{1} \mathrm{H}$ NMR $\left(300 \mathrm{MHz}, \mathrm{CDCl}_{3}\right)$ : $\delta=1.37\left(\mathrm{~s}, \mathrm{C}\left(\mathrm{CH}_{3}\right)_{3}, 18 \mathrm{H}\right), 2.18\left(\mathrm{~s}, \mathrm{CH}_{3}, 6 \mathrm{H}\right), 3.84(\mathrm{~s}$, $\left.\mathrm{Ar}-\mathrm{O}-\mathrm{CH}_{3}, 6 \mathrm{H}\right), 4.98$ (s, Ar- $\left.\mathrm{CH}_{2}, 4 \mathrm{H}\right), 6.79-6.80$ (d, $J=3 \mathrm{~Hz}, A r-\mathrm{H}, 2 \mathrm{H}), 6.86-6.89$ (d, $J=9 \mathrm{~Hz}, A r-\mathrm{H}, 4 \mathrm{H})$, 7.06-7.07 (d, $J=3 \mathrm{~Hz}, A r-\mathrm{H}, 2 \mathrm{H}), 7.48$ (s, $A r-\mathrm{H}, 2 \mathrm{H})$, 7.53-7.56 (d, $J=9 \mathrm{~Hz}, \mathrm{CH}=\mathrm{N}, 2 \mathrm{H}) \mathrm{ppm} ;{ }^{13} \mathrm{C}\left\{{ }^{1} \mathrm{H}\right\} \mathrm{NMR}$ $\left(75 \mathrm{MHz}, \mathrm{CDCl}_{3}\right): \delta=20.40\left(\mathrm{CH}_{3}\right), 29.52\left(\mathrm{C}\left(\mathrm{CH}_{3}\right)_{3}\right)$,

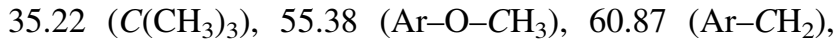
114.31 ( $A r-\mathrm{C}), 122.32$ ( $A r-\mathrm{C}), 123.14$ (Ar-C), 129.35 ( $A r-$ C), 130.23 (Ar-C), 131.16 ( $A r-C), 131.83$ (Ar-C), 133.35 $(A r-\mathrm{C}), 139.33(A r-\mathrm{C}), 159.12(A r-\mathrm{O}), 165.95(\mathrm{CH}=\mathrm{N})$ ppm; IR (ATR): $\bar{v}=1624(-\mathrm{CH}=\mathrm{N}), 1512(\mathrm{Ar}-\mathrm{OMe})$ $\mathrm{cm}^{-1}$; MS (ESI): $\mathrm{m} / \mathrm{z}$ calculated for $\mathrm{C}_{40} \mathrm{H}_{49} \mathrm{~N}_{2} \mathrm{O}_{4} \mathrm{Pd}$ $\left([\mathrm{M}+\mathrm{H}]^{+}\right)$727.27, found 727.60.

\section{X-ray structure determination of compounds 1-3}

Suitable single crystals for X-ray diffraction were grown from concentrated dichloromethane solution of the respective compounds over a period of 7 days. Single crystal analysis were carried out on a Bruker SMART APEX and a Bruker Smart X2S diffractometer operating with Mo $\mathrm{K} \alpha$ radiation $(\lambda=0.71073 \AA)$. The structures were solved by direct methods (SHELXS-97, SIR-97) $[53,54]$ and refined by full-matrix least squares on $F^{2}$ (SHELXL-97) [55]. The $\mathrm{H}$ atoms were calculated geometrically, and a riding model was applied in the refinement process. These data were deposited with CCDC with the following numbers: CCDC 1585795-1585797.
These data can be obtained free of charge from the Cambridge Crystallographic Data Centre at http://www.ccdc. cam.ac.uk. The crystal data are given in Table 4.

Acknowledgements Open access funding provided by Johannes Kepler University Linz. MM thanks for a scholarship within the framework of Erasmus Mundus Action 2 doctoral exchange program of the European Commission. We thank the JKU and Prof. Knör (JKU) for his generous support of the experimental work. The NMR spectrometers were acquired in collaboration with the University of South Bohemia (CZ) with financial support from the European Union through the EFRE INTERREG IV ETC-AT-CZ program (project M00146, "RERI-uasb").

Open Access This article is distributed under the terms of the Creative Commons Attribution 4.0 International License (http:// creativecommons.org/licenses/by/4.0/), which permits unrestricted use, distribution, and reproduction in any medium, provided you give appropriate credit to the original author(s) and the source, provide a link to the Creative Commons license, and indicate if changes were made.

\section{References}

1. Cozzi PG (2004) Chem Soc Rev 33:410

2. Hernández-Molina R, Mederos A (2003) Acyclic and Macrocyclic Schiff Base Ligands. In: McCleverty JA, Meyer TJ (eds) Comprehensive coordination chemistry II, vol 1. Elsevier, p 411

3. Li XF, Li YS (2002) J Polym Sci Part A Polym Chem 40:2680

4. Chellan P, Stringer T, Shokar A, Dornbush PJ, Vazquez-Anaya G, Land KM, Chibale K, Smith GS (2011) J Inorg Biochem 105:1562

5. Cui J, Zhang M, Zhang Y (2010) Inorg Chem Commun 13:81

6. Younkin TR, Connor EF, Henderson JI, Friedrich SK, Grubbs RH, Bansleben DA (2000) Science 287:460

7. Henderson W, Evans C, Nicholson BK, Fawcett J (2003) Dalton Trans:2691

8. Zheng F, Hutton AT, van Sittert CGCE, Moss JR, Mapolie SF (2013) Dalton Trans 42:11163

9. Chellan P, Shunmoogam-Gounden N, Hendricks DT, Gut J, Rosenthal PJ, Lategan C, Smith PJ, Chibale K, Smith GS (2010) Eur J Inorg Chem:3520

10. Komiya N, Okada M, Fukumoto K, Jomori D, Naota T (2011) J Am Chem Soc 133:6493

11. Komiya N, Muraoka T, Iida M, Miyanaga M, Takahashi K, Naota T (2011) J Am Chem Soc 133:16054

12. Mandal M, Oppelt K, List M, Teasdale I, Chakraborty D, Monkowius U (2016) Monatsh Chem 147:1883

13. Xu G, Luo Q, Eibauer S, Rausch RF, Stempfhuber S, Zabel M, Yersin H, Reiser O (2011) Dalton Trans 40:8800

14. Chow PK, Cheng G, Tong GSM, Ma C, Kwok WM, Ang WH, Chung CYS, Yang C, Wang F, Che CM (2016) Chem Sci 7:6083

15. Tong GSM, Chow PK, To WP, Kwok WM, Che CM (2014) Chem Eur J 20:6433

16. Williams JAG (2007) Top Curr Chem 281:205

17. Yersin H, Rausch AF, Czerwieniec R, Hofbeck T, Fischer T (2011) Coord Chem Rev 255:2622

18. Saha TK, Mandal M, Chakraborty D, Ramkumar V (2013) New J Chem 37:949

19. Mandal M, Monkowius U, Chakraborty D (2016) New J Chem 40:9824 
20. Chakraborty D, Chokkapu ER, Mandal M, Gowda RR, Ramkumar V (2016) ChemistrySelect 1:5218

21. Rajashekhar B, Mandal M, Chakraborty D, Ramkumar V (2017) ChemistrySelect 2:8408

22. Mandal M, Monkowius U, Chakraborty D (2016) J Polym Res 23:220

23. Saha TK, Mandal M, Thunga M, Ramkumar V, Chakraborty D (2013) Dalton Trans 42:10304

24. Ragauskas AJ, Williams CK, Davison BH, Tschaplinski T (2006) Science 311:484

25. Williams CK, Hillmyer MA (2008) Polym Rev 48:1

26. Dove AP (2008) Chem Commun 48:6446

27. Nicolas J, Mura S, Brambilla D, Mackiewicz N, Couvreur P (2013) Chem Soc Rev 42:1147

28. Dechy-Cabaret O, Martin-Vaca B, Bourissou D (2004) Chem Rev 104:6147

29. Jerome C, Lecomte P (2008) Adv Drug Delivery Rev 60:1056

30. Mandal M, Chakraborty D (2016) J Polym Sci Part A Polym Chem 54:809

31. Mandal M, Chakraborty D, Ramkumar V (2015) RSC Adv 5:28536

32. Tsai C-Y, Du H-C, Chang J-C, Huang B-H, Ko B-T, Lin C-C (2014) RSC Adv 4:14527

33. Wang L, Poirier V, Ghiotto F, Bochmann M, Cannon RD, Carpentier J-F, Sarazin Y (2014) Macromolecules 47:2574

34. Aluthge DC, Patrick BO, Mehrkhodavandi P (2013) Chem Commun 49:4295

35. Sauer A, Kapelski A, Fliedel C, Dagorne S, Kol M, Okuda J (2013) Dalton Trans 42:9007

36. Dagorne S, Normand M, Kirillov E, Carpentier J-F (2013) Coord Chem Rev 257:1869

37. Nie K, Gu W, Yao Y, Zhang Y, Shen Q (2013) Organometallics 32:2608

38. Joshi H, Prakash O, Sharma AK, Sharma KN, Singh AK (2015) Eur J Inorg Chem: 1542

39. Blackburn OA, Coe BJ, Fielden J, Helliwell M, McDouall JJW, Hutchings MG (2010) Inorg Chem 49:9136
40. Roy S, Saha R, Mondal TK, Sinha C (2014) Inorg Chim Acta 423:52

41. Feng ZQ, Yang XL, Ye YF, Hao LY (2014) Bull Korean Chem Soc 35:1121

42. Khorshidifard M, Rudbari HA, Askari B, Sahihi M, Farsani MR, Jalilian F, Bruno G (2015) Polyhedron 95:1

43. Tajuddin AM, Bahron H, Zaki HM, Kassim K, Chantrapromma S (2015) Acta Crystallogr E71:350

44. Kasumov VT, Köksal F, Sezer A (2005) Polyhedron 24:1203

45. Bhunora S, Mugo J, Bhaw-Luximon A, Mapolie S, Wyk JV, Darkwa J, Nordlander E (2011) Appl Organomet Chem 25:133

46. Swierczynski D, Luboradzki R, Dolgonos G, Lipkowski J, Schneider H-J (2005) Eur J Org Chem:1172

47. Nagels N, Hauchecorne D, Herrebout WA (2013) Molecules $18: 6829$

48. Masutani K, Yoshiharu K (2015) PLA Synthesis and Polymerization. In: Jiménez A, Peltzer M, Ruseckaite R (eds), Poly(lactic acid) science and technology: processing, properties, additives and applications. RSC polymer chemistry series no. 12, The Royal Society of Chemistry, p 3

49. Kricheldorf HR, Mang T, Jonte JM (1984) Macromolecules 17:2173

50. Dubois P, Jacobs C, Jérôme R, Teyssié P (1991) Macromolecules 24:2266

51. Stevels WM, Ankone MJ, Dijkstra PJ, Feijen J (1996) Macromolecules 29:6132

52. Chamberlain BM, Jazdzewski BA, Pink M, Hillmyer MA, Tolman WB (2000) Macromolecules 33:3970

53. Sheldrick GM (1997) SHELXS-97, program for the solution of crystal structures. Göttingen, Germany. See also: Sheldrick GM (1990). Acta Crystallogr A46:467

54. Altomare A, Burla MC, Camalli M, Cascarano GL, Giacovazzo C, Guagliardi A, Moliterni AGG, Polidori G, Spagna R (1999) J Appl Cryst 32:115

55. Sheldrick GM (1997) SHELXL-97, program for crystal structure refinement. Göttingen, Germany. See also Sheldrick GM (2008). Acta Crystallogr A64:112 